\title{
Science champion joins US election race
}

\section{Colin Macilwain, Washington}

For most Americans and foreign observers, $\mathrm{Al}$ Gore's selection of Senator Joseph Lieberman (Democrat, Connecticut) as his running mate in November's presidential election was noteworthy for the senator's religious affiliation: he is an orthodox Jew.

But for the scientific community, it means something else. Lieberman, a 58-year-old lawyer, is one of science's strongest supporters in the Congress. And if the Gore-Lieberman ticket triumphs, he is likely to play an active role in shaping US science policy.

Lieberman is one of perhaps half-adozen senators with a genuine interest in research issues. He helped to found a science and technology caucus in the Senate, and led congressional efforts to pass bipartisan legislation endorsing the idea of doubling the budgets of all of the major civilian research agencies over the next 10 or 12 years.

Lieberman introduced the first 'doubling bill' with Phil Gramm (Republican, Texas) in 1997, and later supported a more recent version sponsored by Bill Frist (Republican, Tennessee) and Jay Rockefeller (Democrat, West Virginia).

The Senate passed this measure unanimously last October, and the House of Representatives may consider it next month. Scientific societies see it as an important statement of support for agencies other than

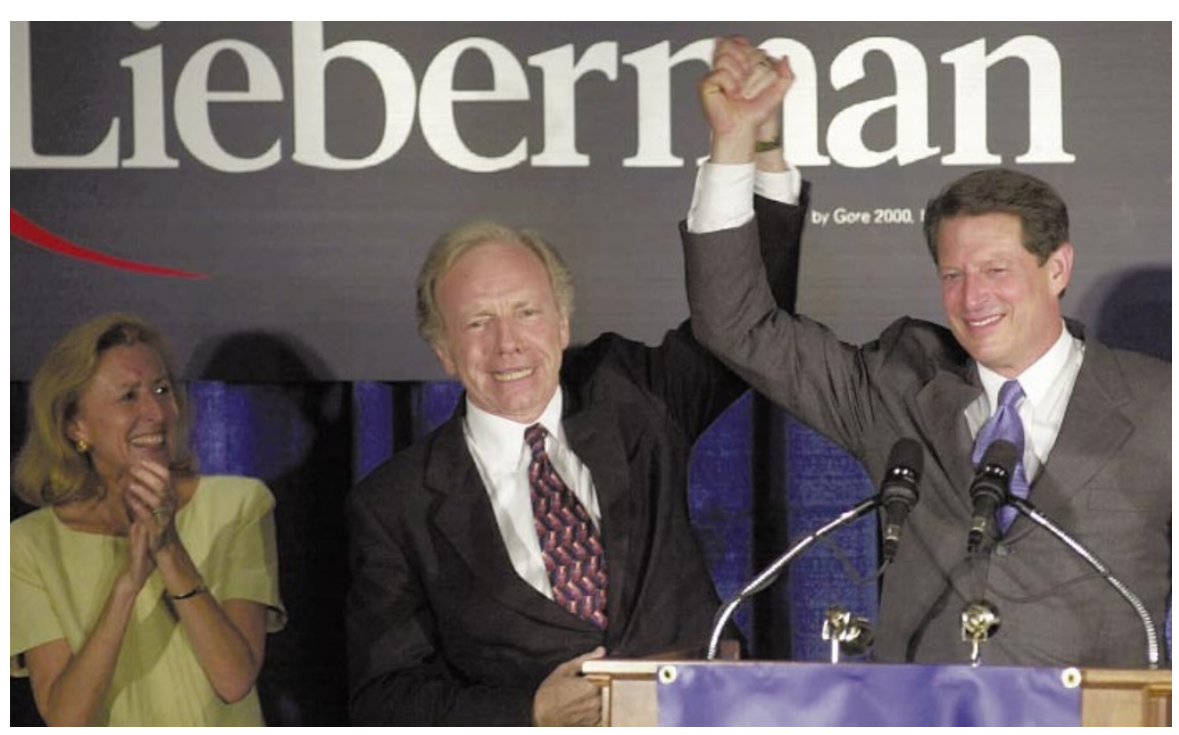

Dream team? Both Lieberman (centre) and Gore (right) are strong advocates of science.

the National Institutes of Health, which is already assured of congressional backing.

Michael Lubell, head of public affairs at the American Physical Society, describes Lieberman as "the primary ingredient" in the doubling bill's progress, because of his ability to reach across party lines to build support. "He's got a very strong interest in science and technology, and complements Gore extremely well in that regard," he says.

\section{Chemist tipped for top UK science post}

\section{David Dickson, London}

One of Britain's leading physical chemists, well known in his field but less prominent in policymaking circles, is tipped to become the UK government's next chief scientific adviser and head of the Office of Science and Technology. David King, master of Downing College, Cambridge, and head of the department of chemistry at the University of Cambridge since 1993, is said to have been picked for the post from a short list of three.

No formal offer has yet been made to King, who is currently on holiday. But time is pressing the five-year contract of the present chief scientist, Sir Robert May, expires at the end of August, when he will start his new job as president of the Royal Society.

Born in South Africa, King studied at the University of Witwatersrand and at Rand

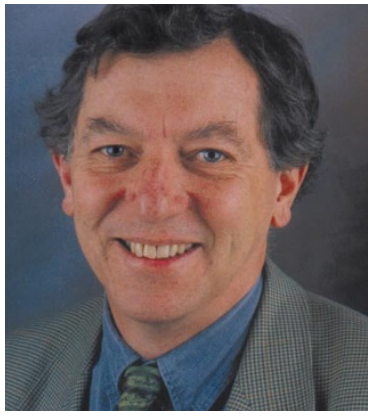

King: the next chief scientist?

University before coming to England. He was a lecturer at the University of East Anglia in Norwich before being appointed professor of physical chemistry at the University of Liverpool in 1974. He has been at Cambridge since 1988.

During his time at Cambridge, King, a specialist in the physics and chemistry of solid surfaces, has held several seniof: in the Royal Society of Chemistry, and has been an editor of Chemical Physics Letters since 1989. He has also held a number of advisory appointments and teaching commitments in Europe, and became a Fellow of the Royal Society in 1991.

Despite his low profile in government circles, he is no stranger to the political issues concerning university researchers, having been on the national executive of the Association of University Teachers from 1970 to 1978 , and the union's president in 1976-77.

"Being science adviser sounds like his sort of job," says one chemist. "He is very good at running things, and has a reputation as a keen and efficient administrator." If King's appointment is confirmed, he is believed to be the first chemist to Madrailtaocumpiazthe $\$$ estusince it was created.
The Connecticut senator is a founding member, with Frist, Rockefeller and Pete Domenici (Republican, New Mexico), of the science and technology caucus in the Senate, an informal group that meets about once a month and serves as a sounding-board for science and technology issues.

Jack Gibbons, a former science adviser to President Bill Clinton, says that Lieberman "appreciates the aesthetic as well as the economic value of research" and "has always worked hard for the research and development budget".

Lieberman had an early interest in arms control, writing a book on it in 1970. But, according to several sources, he developed an interest in technology policy largely through his involvement in small business and security issues, both of which reflected the economic needs of his home state.

Later, he became a champion for basic scientific research. He sits on the Senate Armed Services Committee and recently convened a conference between generals and scientists to discuss the future of warfare.

"He's been a long-time advocate of science and technology," says David Schutt, head of legislative affairs at the American Chemical Society, adding that Lieberman is involved "whenever there is a bill out there" to boost research.

No one expects science and technology to play much of a role in the presidential campaign. George W. Bush, the Republican candidate, has already promised to double military research and development if he is elected, and both parties will portray themselves as strong supporters of research.

But observers in Washington point out that the Gore-Lieberman ticket is an unusual combination: two lay politicians who take more than a passing interest in science. 